\title{
Inhibition of IgE Antibody Formation by n-Pentyl $a$-L-Sorbopyranoside
}

\author{
Naoki INAGAKI, Akihide KODA, Akira YAGI*, Yasushi HARAGUCHI**, \\ Hiroichi NAGAI, Kanji NODA** and Itsuo NISHIOKA* \\ Department of Pharmacology, Gifu Pharmaceutical University. \\ Mitahora-higashi, Gifu 502, Japan \\ *Faculty of Pharmaceutical Sciences, Kyushu University. \\ Maidashi, Higashi-ku, Fukuoka 812, Japan \\ * Research Laboratory. Hisamitsu Pharmaceutical Co., Ltd.. \\ Tashiro, Tosu, Saga 841, Japan
}

Accepted September 13, 1985

\begin{abstract}
Effect of $n$-pentyl glycosides and alkyl $\alpha$-L-sorbopyranosides on IgE antibody formation in rats and mice were investigated. When $n$-pentyl $\alpha$ - Lsorbopyranoside was given subcutaneously or orally, the IgE antibody formation in rats and mice was suppressed, while no suppression of hemagglutinin formation was observed. The study on timing of administration indicated that $n$-pentyl $\alpha$-L-sorbopyranoside significantly suppressed the secondary IgE antibody response when administered before the secondary immunization.
\end{abstract}

By the screening of alcoholic or aqueous extracts of twenty traditional Chinese crude drugs which had been widely used for diseases caused by allergies, alcoholic extracts of Zizyphus Fructus and Gentianae scabrae Radix were found to suppress the $\lg \mathrm{E}$ antibody formation in rats immunized with dinitrophenylated Ascaris suum extract (DNP-As) (1). Alcoholic extract of Zizyphus Fructus was less suppressive in hemolytic plaque forming cell (HPFC) formation in spleens of mice immunized with sheep red blood cells (SRBC) than that of Geutianae scabrae Radix. Furthermore, alcoholic extract of Zizyphus Fructus directly suppressed 48$\mathrm{hr}$ homologous passive cutaneous anaphylaxis (48-hr homologous PCA) in rats sensitized with anti-DNP-As IgE serum. These results suggested that the alcoholic extract of Zizyphus Fructus has constituents which suppress the $\lg E$ antibody formation without affecting the generation of $\mathrm{IgM}$ antibody forming cells and directly suppress the PCA.

Chemical and immunological studies on the alcoholic extract of Zizyphus Fructus demonstrated that ethyl $\alpha$-D-fructofura- noside, a configurational and conformational isomer of ethyl D-fructosides, was identified as one of the active components which suppress the $\lg E$ antibody formation (2). In an earlier experiment on derivatization of alkyl $D$-fructosides, it was found that $n$-pentyl $\beta$-D-fructopyranoside given either i.p. or p.o. effectively suppressed the IgE antibody formation in both rats and mice without any suppression of hemagglutinin (HA) formation (3).

In order to find out a more specific and more potent inhibitor of $\mathrm{ggE}$ antibody formation, the screening of various synthesized alkyl glycosides to $\lg E$ antibody and HA formations was undertaken. This paper describes how $n$-pentyl $\alpha$-L-sorbopyranoside suppresses the $\lg E$ antibody formation in connection with the action of $n$-pentyl $\beta$-Dfructopyranoside (3).

\section{Materials and Methods}

Animals: Male and female Wistar rats of 9-10 weeks of age, male and female ddy mice of 7 weeks of age and female BALB/c mice of 7-11 weeks of age were obtained from Shizuoka Laboratory Animal Center (Shizuoka 
Japan). They were fed laboratory chow and water ad libitum.

Alkyl glycosides: Alkyl glycosides were prepared in good yields by a modification of the standard method. In a typical experiment, dried L-sorbose $(10.0 \mathrm{~g})$ was dissolved in $\mathrm{n}$-pentyl alcohol $(490 \mathrm{ml})$ and kept at $140^{\circ} \mathrm{C}$ for $2 \mathrm{hr}$. Then, sulfuric acid $(0.2 \mathrm{~g})$ was added to the solution and was allowed to stand for $24 \mathrm{hr}$ at room temperature. The reaction mixture was neutralized with $25 \%$ ammonia, the precipitate was filtrated off; and the filtrate was concentrated to a syrup. The syrup containing conformational and configurational isomers was chromatographed over a silica-gel column, using EtOAc saturated with $\mathrm{H}_{2} \mathrm{O}$ or $\mathrm{CHCl}_{3}-\mathrm{EtOH}-\mathrm{H}_{2} \mathrm{O}$ $(7: 3: 1)$ as a solvent, to give $8.0 \mathrm{~g}$ of $\mathrm{n}$ pentyl $\alpha$-L-sorboside in a pure $L$-sorbopyranoside form. On a large scale production. however, the yield of $n$-pentyl $\alpha$-Lsorbopyranoside decreased to $66 \%$. In the same way, the formation of alkyl glycosides was undertaken to yield a mixture of conformational and configurational isomers, each of which was purified by means of silica-gel chromatography.

Melting points were determined on a Yanagimoto melting point apparatus and are uncorrected.

Optical rotation was measured in a $\mathrm{MeOH}$ solution on a JASCO DIP-SL automatic polarimeter at $22^{\circ} \mathrm{C}$.

${ }^{13} \mathrm{C}$ nuclear magnetic resonance (NMR) spectra of the $0.5 \mathrm{M} \mathrm{CD}_{3} \mathrm{OD}$ solution were recorded at $22^{\circ} \mathrm{C}$ in a $5 \mathrm{~mm}$ spinning tube with the JEOL FX-100 using $\mathrm{Me}_{4} \mathrm{Si}$ as the internal standard $(25.5 \mathrm{MHz})$. Fourier transform measurement conditions: spectral width, $47.3 \mathrm{KHz}$; pulse flipping angle, 45$90^{\circ}$; number of data points, 8192: pulse repetition, $3 \mathrm{sec}$.

Mass spectral data were recorded on a JEOL-D 100 mass spectrometer with an accelerating potential of $30 \mathrm{eV}$ and a source temperature at $170^{\circ} \mathrm{C}$.

Gas liquid chromatography (GLC) analyses were performed on a Shimadzu GC4BM gas chromatograph equipped with flame ionization detectors, and carried out on permethyl ethers (condition $A$ ) and on the trimethylsilyl (TMS) ether (condition B) of alkyl L-sorbosides with an on column system. Condition A: 5\% 1,4-butanediol succinate, Shimalite $W$ (60-80 mesh), $3 \mathrm{~mm} \phi \times 2 \mathrm{~m}$ glass column, column temperature of $175^{\circ} \mathrm{C}$, detector temperature at $220^{\circ} \mathrm{C}$, carrier gas $\mathrm{N}_{2}$ at $40 \mathrm{ml} / \mathrm{min}$. Condition B: $2 \%$ silicone OV 17, Chromosorb W (AW-DMCS, 60-80 mesh), $3 \mathrm{~mm} \phi \times 2 \mathrm{~m}$ glass column, column temperature of $200^{\circ} \mathrm{C}$, carrier gas $\mathrm{N}_{2}$ at 40 $\mathrm{ml} / \mathrm{min}$.

Immunization: Female Wistar rats and BALB/C mice were used for the formation of antibodies. Throughout the experiment, DNPAs was used as an antigen. The preparation of DNP-As was as follows: An extract from Ascaris suum prepared by the method of Strejan and Campbell (4) was dinitrophenylated with 2,4-dinitrobenzene sulfonic acid by the method of Eisen et al. (5). The reaction mixture was dialyzed to remove uncoupled reagent, then, lyophilized and stored at $-20^{\circ} \mathrm{C}$. Protein content of the antigen measured by the micro-biuret method (6) was $21.0 \%$, and the amount of antigen employed in this experiment was expressed as the amount of protein. As adjuvants, killed Bordetella pertussis (killed B. pertussis). $2 \times 10^{10} / \mathrm{ml}$, supplied by Kaken Pharmaceutical Co., Ltd., and aluminium hydroxide gel (alum) were used for rats and mice, respectively. Alum was prepared by the method of Levine and $\operatorname{Vaz}(7)$ with slight modifications. Briefly, a mixture of equal volume of $2 \mathrm{~N}$ aluminium sulfate and $2 \mathrm{~N}$ sodium hydroxide was stirred for $10 \mathrm{~min}$ at room temperature. Then, the precipitate was further stirred with a Polytron (Kinematica $\mathrm{GmbH}$ ) and washed with distilled water until no sulfate ion could be detected in the supernatant. Finally, alum was suspended in $0.02 \mathrm{M}$ borate buffered saline $(\mathrm{pH} \mathrm{8.0)}$ in a concentration of $20 \mathrm{mg} / \mathrm{ml}$.

According to the method of Tada and Okumura (8), rats were immunized with $1 \mathrm{mg}$ of DNP-As and $10^{10}$ of killed B. pertussis (Day 0 ). Five days later (Day 5 ), they were boosted with $0.5 \mathrm{mg}$ of DNP-As alone. On Day 8 , rats were sacrificed, and the serum was obtained from each rat.

Mice were immunized i.p. with $10 \mu \mathrm{g}$ of DNP-As and $2 \mathrm{mg}$ of alum or $2.5 \mu \mathrm{g}$ of DNPAs and $0.5 \mathrm{mg}$ of alum. In some experiments, 
mice were immunized secondarily (2nd immunization) in the same way as the primary (1st) immunization. They were bled at appropriate intervals, and sera were separated.

Serum samples obtained from rats and mice were stored at $-20^{\circ} \mathrm{C}$ until the time of assay. Test compounds were dissolved in physiological saline and given s.c. to the animals for 5 days before or after the immunization. In some experiments, test compounds were dissolved in $2 \% \mathrm{NaHCO}_{3}$ solution and administered p.o. Control animals received the vehicle only, except for the non-treated control.

Evaluation of $\lg E$ antibody: Serum $\lg E$ antibody levels were evaluated by the PCA according to the technique described by Ovary (9). Briefly, 2-fold serially diluted serum samples were injected intradermally into the shaved backs of normal male Wistar rats in duplicate. A twenty-four-hr sensitization period was used for mouse $\mathrm{IgE}$ antibody, and a 48-hr sensitization period was used for rat $\lg E$ antibody. PCA was elicited by an intravenous injection of $1 \mathrm{ml}$ of saline containing $1 \mathrm{mg}$ of DNP-As and $5 \mathrm{mg}$ of Evans blue dye. Thirty min after the injection, rats were sacrificed, and the PCA titer was measured. The PCA titer recorded is the greatest dilution that gave a positive skin reaction.

Evaluation of hemagglutinin (HA): The passive hemagglutination test was carried out by the method of Avrameas et al. (10). Serum samples were serially diluted in microtiter plates, and each portion of the serum $(50 \mu \mathrm{l})$ was mixed with $50 \mu \mathrm{l}$ of DNPAs tanned SRBC suspension. After incubation for $2 \mathrm{hr}$ at $37^{\circ} \mathrm{C}$, the agglutinations at the bottom of the plates were evaluated. The HA titer recorded is the greatest dilution that gave complete agglutination.

Toxicity test: Toxicity of alkyl glycosides was estimated as follows: Test compounds, in doses of $0.3,0.5,1,2$ and $5 \mathrm{~g} / \mathrm{kg}$, were given to ddY mice or Wistar rats by various routes. In p.o. administration, animals were fasted for 6 to $8 \mathrm{hr}$ before the administration. After the observation period of 21 days, the number of survivals were counted.

Statistical analysis: Titers given in the tables are the mean except for the value obtained from pooled sera. Difference between the control group and the experimental group was statistically evaluated by Wilcoxon's $U$-test (11).

\section{Results}

Effect of $n$-pentyl glycosides on antibody formations in mice: Nine kinds of $n$-pentyl glycosides were synthesized by the method described in the experimental section, and pyranosides of $\beta$-D-arabinose, $\beta$-Dgalactose, $\alpha$-L-sorbose and $\beta$-D-ribofuranose were obtained as a pure form. The physical properties of these compounds are shown in Table 1. To investigate the effect of these compounds on antibody formations, mice were immunized with $10 \mu \mathrm{g}$ of DNP-As and $2 \mathrm{mg}$ of alum, and these compounds were given at $100 \mathrm{mg} / \mathrm{kg}$ for 5 days from the day of immunization. Ten days after the immunization, mice were bled and serum samples were collected. Table 1 shows that $n$-pentyl $\alpha$-L-sorbopyranoside given S.C. (Exp. I) reduced the PCA titer and that $n$ pentyl $\beta$-D-ribofuranoside, $n$-pentyl $\beta$-Dgalactopyranoside, $n$-pentyl $\alpha, \beta$-L-rhamnopyranoside and $\mathrm{n}$-pentyl $\alpha$-L-sorbopyranoside dissolved in $2 \% \mathrm{NaHCO}_{3}$ solution and given p.o. (Exp. II) reduced the PCA titer. All these compounds showed almost no reducing effect on the $\mathrm{HA}$ titer.

Physical properties of alkyl $\boldsymbol{\alpha}$-L-sorbopyranosides and their effect on antibody formations: As n-pentyl $\alpha$-L-sorbopyranoside suppressed the $\lg E$ antibody formation without affecting the HA formation, several alkyl $\alpha$-L-sorbopyranosides were synthesized, and the effect on antibody formations were investigated. ${ }^{13} \mathrm{C}$ NMR spectral data and other physical properties of alkyl $\alpha$-Lsorbopyranosides synthesized are shown in Tables 2 and 3 . The effect of these compounds on antibody formations in rats is shown in Table 3. Rats received these compounds at $100 \mathrm{mg} / \mathrm{kg}$. s.c., for 5 days from Day 0. nButyl $\alpha$-L-sorbopyranoside reduced the PCA titer, but $n$-pentyl $\alpha$-L-sorbopyranoside only showed a tendency to do so. These compounds did not reduce the HA titer. The effects of these compounds in mice are shown in Table 4 . In two experiments, mice 
Table 1. Effect of $n$-pentyl glycosides on IgE antibody and hemagglutinin (HA) formations in female $\mathrm{BALB} / \mathrm{c}$ mice

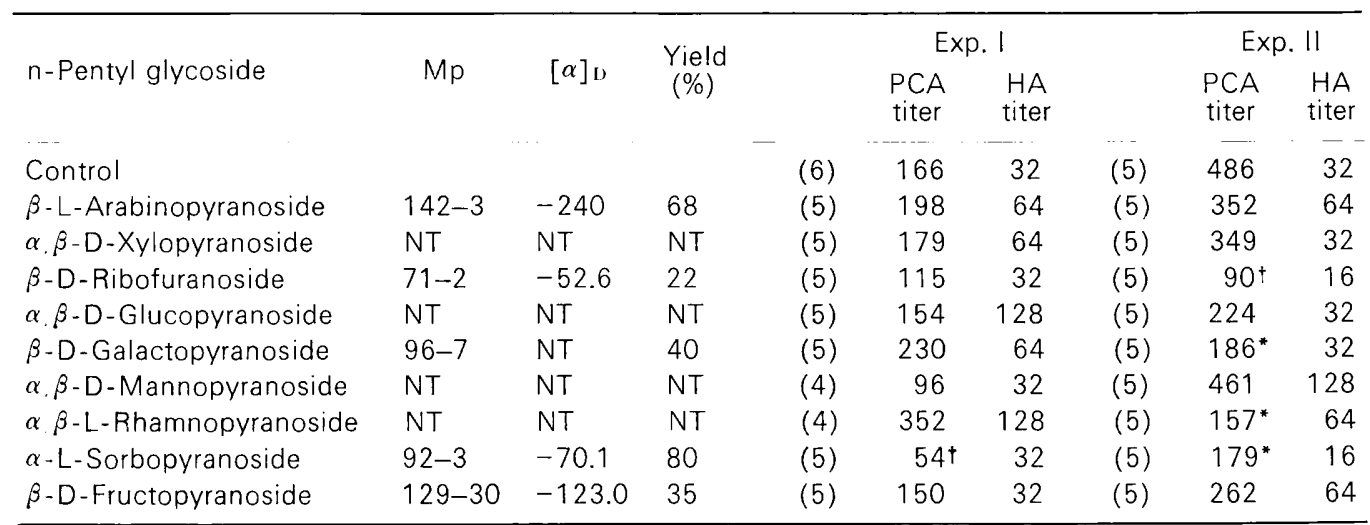

Mice were immunized with $10 \mu \mathrm{g}$ of DNP-As and $2 \mathrm{mg}$ of alum on Day 0 . n-Pentyl glycosides were given $100 \mathrm{mg} / \mathrm{kg} /$ day. s.c., in Exp. I and p.o. in Exp. 11 for 5 days from Day 0. In p.o. administration, $n$-pentyl glycosides were dissolved in $2 \% \mathrm{NaHCO}_{3}$ solution. Serum was collected from each mouse on Day 10 to estimate antibody titers. PCA titers are represented as the mean, and HA titers are values estimated with pooled sera. Figures in parentheses indicate the number of mice used. ${ }^{*} P \leqq 0.05$, t: P $\leq 0.01$, NT: Not tested.

were immunized with $10 \mu \mathrm{g}$ of DNP-As and $2 \mathrm{mg}$ of alum on Day 0 , and serum samples were obtained on Day 10. Test compounds were given $100 \mathrm{mg} / \mathrm{kg} /$ day, s.c., for 5 days from Day 0 in both Exp. I and II. In Exp. I. n-butyl $\alpha$-L-sorbopyranoside reduced the PCA titer without affecting the HA titer, but n-pentyl $\alpha$-L-sorbopyranoside did not reduce the PCA titer. In Exp. II, n-pentyl and $n$-hexyl $\alpha$-L-sorbopyranosides reduced the PCA titer.

Effect of $n$-pentyl $\beta$-D-fructopyranoside, n-butyl $\boldsymbol{\alpha}$-L-sorbopyranoside and $\mathrm{n}$-pentyl $\boldsymbol{\alpha}$-L-sorbopyranoside on antibody formations in mice: The possibility was indicated that $n$ butyl and $n$-pentyl $\alpha$-L-sorbopyranosides suppress the $\operatorname{lgE}$ antibody formation in rats and mice without suppressing the HA formation. As shown in Table 5, toxicities of these two compounds were very low. Then, further experiments were performed in connection with the action of $n$-pentyl $\beta$-Dfructopyranoside reported previously (3).

First, the timing of administration of these compounds was investigated in mice. Mice were immunized with $2.5 \mu \mathrm{g}$ of DNP-As and $0.5 \mathrm{mg}$ of alum, twice, on Days 0 (1 $1 \mathrm{st} \mathrm{im}$ munization) and 30 (2nd immunization), in the same way. Administrations, $100 \mathrm{mg} / \mathrm{kg} /$ day, s.c., for 5 days, of these compounds were performed as follows: 1) before the 1st immunization (Day -4 0), 2) after the 1st immunization (Day 0 4), 3) before the 2nd immunization (Day 26 30), and 4) after the 2nd immunization (Day 30 34). As shown in Table $6, n$-pentyl $\beta$-D-fructopyranoside administered after the 1st immunization reduced the PCA titer throughout the experiment. These alkyl glycosides given before the 2nd immunization significantly reduced the PCA titer on Day 37. In the case that these compounds were given after the $1 \mathrm{st}$ and before or after the 2nd immunization, the HA titer on Day 37 was significantly increased.

Next, the studies on dose-dependency of these compounds were carried out in mice. Mice were immunized with $2.5 \mu \mathrm{g}$ of DNPAs and $0.5 \mathrm{mg}$ of alum, twice, on Days 0 and 36. The three alkyl glycosides were given $10-200 \mathrm{mg} / \mathrm{kg} /$ day, s.c., for 5 days from Day 0 . As shown in Table 7, n-pentyl $\alpha$-Lsorbopyranoside given in doses of 20 200 $\mathrm{mg} / \mathrm{kg}$ reduced the PCA titer throughout the experiment, but a clear dose-dependency was not observed. The HA titer in this experiment was not reduced at any time.

$n$-Pentyi $\beta$-D-fructopyranoside and $n$ butyl $\alpha$-L-sorbopyranoside were less effective 


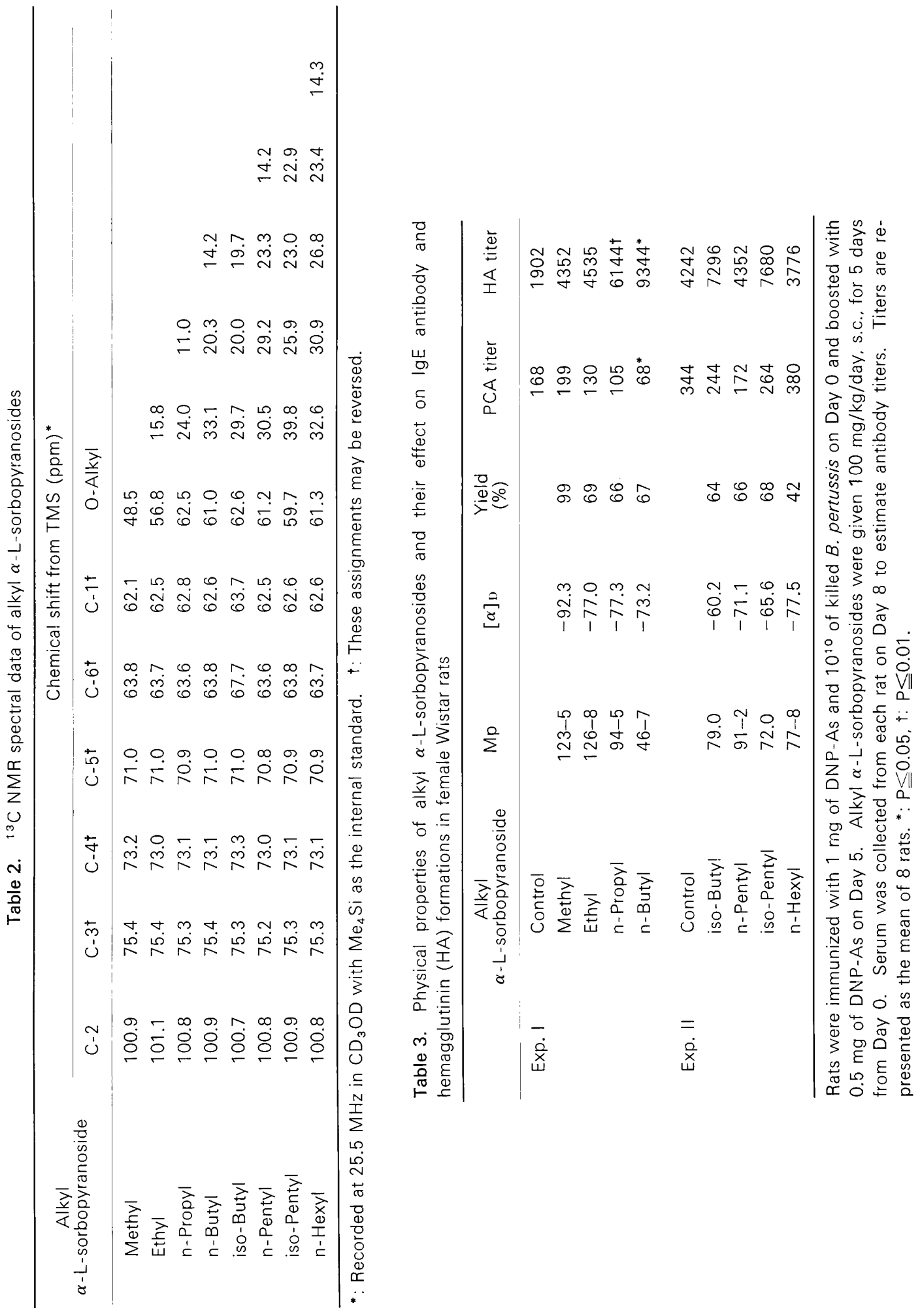


Table 4. Effect of alkyl $\alpha$-L-sorbopyranosides on $\operatorname{lgE}$ antibody and hemagglutinin (HA) formations in female BALB/c mice

\begin{tabular}{llccccc}
\hline \multicolumn{1}{c}{ Alkyl } & \multicolumn{3}{c}{ Exp. I } & \multicolumn{2}{c}{ Exp. II } \\
$\alpha$-L-sorbopyranoside & & PCA titer & HA titer & & PCA titer & HA titer \\
\hline Control & $(8)$ & 480 & 112 & $(7)$ & 841 & 567 \\
Methyl & $(6)$ & 512 & $256^{*}$ & $(4)$ & 544 & 256 \\
Ethyl & $(6)$ & 427 & 160 & $(4)$ & 800 & 384 \\
n-Propyl & $(6)$ & 373 & 160 & $(4)$ & 704 & 320 \\
n-Butyl & $(6)$ & $256^{*}$ & 107 & $(4)$ & 1024 & 320 \\
iso-Butyl & $(6)$ & 469 & 117 & $(4)$ & 800 & 160 \\
n-Pentyl & $(6)$ & 416 & 139 & $(4)$ & $416^{*}$ & 384 \\
iso-Pentyl & $(6)$ & 448 & 149 & $(4)$ & 896 & 416 \\
n-Hexyl & $(6)$ & 448 & 117 & $(4)$ & $416^{*}$ & 160 \\
\hline
\end{tabular}

Mice were immunized with $10 \mu \mathrm{g}$ of DNP-As and $2 \mathrm{mg}$ of alum on Day 0 , and alkyl $\alpha$-L-sorbopyranosides were given $100 \mathrm{mg} / \mathrm{kg} /$ day, s.c., for 5 days from Day 0 in both Exp. I and II. Serum was collected from each mouse on Day 10 to estimate antibody titers. Titers are represented as the mean, and figures in parentheses indicate the number of mice used. ${ }^{*}: \mathrm{P} \leqq 0.05$.

Table 5. Toxicity of $n$-butyl and n-pentyl $\alpha$-L-sorbopyranosides

\begin{tabular}{|c|c|c|c|c|c|}
\hline \multirow{3}{*}{ Route } & \multirow{3}{*}{ Sex } & \multicolumn{4}{|c|}{ Toxic dose $(\mathrm{g} / \mathrm{kg})$} \\
\hline & & \multicolumn{2}{|c|}{$\begin{array}{c}\mathrm{n} \text {-Butyl } \\
\alpha \text {-L-sorbopyranoside }\end{array}$} & \multicolumn{2}{|c|}{$\begin{array}{c}n \text {-Pentyl } \\
\alpha \text {-L-sorbopyranoside }\end{array}$} \\
\hline & & Rat & Mouse & Rat & Mouse \\
\hline \multirow[t]{2}{*}{ p.o. } & male & $>5$ & $>5$ & $>5$ & $5 \sim 2$ \\
\hline & female & NT & NT & $>5$ & $5 \sim 2$ \\
\hline \multirow[t]{2}{*}{ s.c. } & male & $>5$ & $>5$ & $>5$ & 2 \\
\hline & female & NT & NT & $>5$ & 2 \\
\hline \multirow[t]{2}{*}{ i.p. } & male & $>5$ & $>1$ & 2 & $1 \sim 0.5$ \\
\hline & female & NT & NT & 2 & $1 \sim 0.5$ \\
\hline \multirow[t]{2}{*}{ i.v. } & male & $>2$ & $>2$ & $2 \sim 1$ & $2 \sim 1$ \\
\hline & female & NT & NT & $2 \sim 1$ & $2 \sim 1$ \\
\hline
\end{tabular}

Each value represents the dose or dose range which gave $50 \%$ lethality.

than $\mathrm{n}$-pentyl $\alpha$-L-sorbopyranoside in this experiment (data not shown).

\section{Discussion}

Allergic disorders such as bronchial asthma and hay fever are caused by $\lg E$ antibody as classified by Ishizaka et al. (12). This suggests, therefore, a possible therapy for allergic disorders by regulating the $\lg \mathrm{E}$ antibody level. Several attempts to modulate the IgE antibody response have been made by a number of investigators. Urea-denatured antigens suppress the $\lg E$ antibody response not only in the primary response but also in the ongoing response in mice immunized with native antigens $(10,12-15)$. It has been shown that modified antigens such as ovalbumin-polyethylene glycol (16), ovalbumin-pullulan (17), DNP-isologous protein (18), DNP-mycobacterium (19), DNPFicoll (20), DNP-liposome (21), DNPpolyvinyl alcohol (22), and passively administered antibody $(8,23)$ suppressed the $\lg E$ antibody response. Furthermore, orally administered antigen (24) and aerosolized antigen (25) suppressed the $\lg E$ antibody response against the antigen. However, all of these methods for the regulation of the $\lg E$ 
Inhibition of IgE Antibody Formation

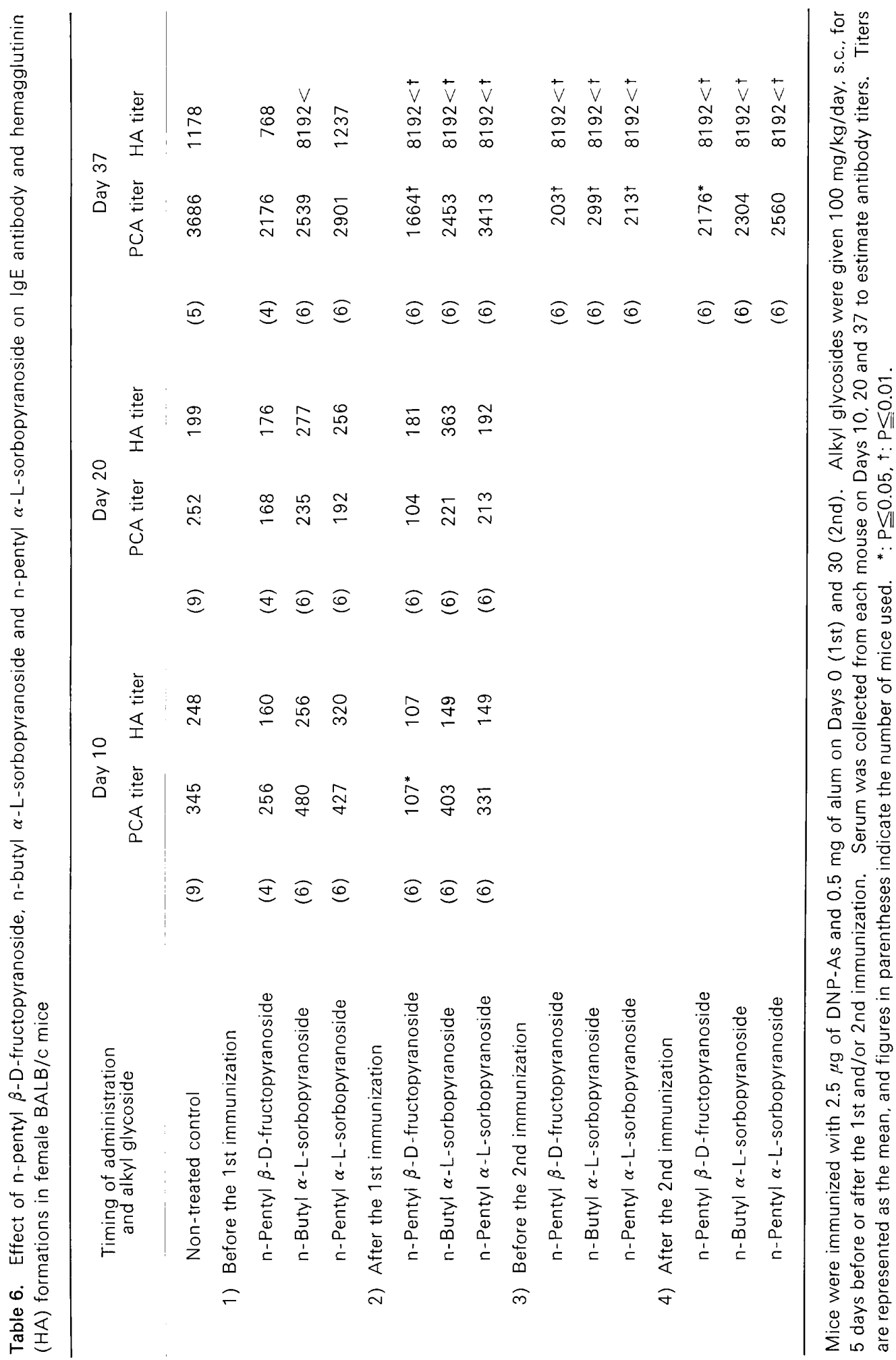


Table 7. Effect of n-pentyl $\alpha$-L-sorbopyranoside on IgE antibody and hemagglutinin (HA) formations in female BALB/c mice

\begin{tabular}{|c|c|c|c|c|c|c|}
\hline \multirow{2}{*}{$\begin{array}{c}n \text {-Pentyl } \\
\alpha-L-s o r b o p y r a n o s i d e \\
(\mathrm{mg} / \mathrm{kg})\end{array}$} & \multicolumn{2}{|c|}{ Day 10} & \multicolumn{2}{|c|}{ Day 20} & \multicolumn{2}{|c|}{ Day 43} \\
\hline & PCA titer & HA titer & PCA titer & HA titer & PCA titer & HA titer \\
\hline$O$ (Control) & 640 & 141 & 138 & 61 & 4301 & 2662 \\
\hline 10 & 282 & 205 & 174 & 96 & 3789 & 2355 \\
\hline 20 & $93^{*}$ & 115 & 74 & 102 & 2202 & 3482 \\
\hline 50 & 179 & 157 & 107 & 51 & $1741^{*}$ & 1946 \\
\hline 100 & 211 & 110 & 53 & 141 & 2867 & 2150 \\
\hline 200 & 173 & 102 & 84 & 96 & $1792^{*}$ & 2458 \\
\hline
\end{tabular}

Mice were immunized with $2.5 \mu \mathrm{g}$ of DNP-As and $0.5 \mathrm{mg}$ of alum on Days 0 and 36 . Five doses of $n$-pentyl $\alpha$-L-sorbopyranoside were given s.c. for 5 days from Day 0 . Serum was collected from each mouse on Days 10, 20 and 43 to estimate antibody titers. Titers are represented as the mean of 5 mice. * $: P \leqq 0.05$.

antibody formation provided only an antigenspecific activity. Recently. Nakashima et al. (26) reported that polysaccharide fractions prepared from a mushroom, Baikisei Ganoderma applanatum, suppressed the $\operatorname{lgE}$ antibody formation in mice, and this suppression was IgE class-selective and antigennon-specific.

In order to find a new type of agent which suppresses the IgE antibody formation, extracts from twenty traditional Chinese crude drugs which had been used for allergic disorders were examined, and alcoholic extract of Zizyphus Fructus was found to suppress the $\operatorname{Ig} E$ antibody formation in rats immunized with DNP-As without affecting the generation of $\operatorname{lgM}$ antibody forming cells (1). Previous experiments indicated that ethyl $\alpha$-D-fructofuranoside was one of the active components of the alcoholic extract of Zizyphus Fructus (2), and n-pentyl $\beta$-Dfructopyranoside, one of the derivatives of ethyl $\alpha$-D-fructofuranoside, revealed a potent effect (3).

Further studies of $n$-pentyl glycosides and alkyl $\alpha$-L-sorbosides on the IgE antibody formation in rats and mice immunized with DNP-As were undertaken to find an antigenindependent and more potent drug.

The purity of each n-pentyl glycoside separated on chromatography was examined by means of gas chromatographical analyses of the trimethylsilyl derivatives. The ring size and anomeric nature were assigned to be glycosides by means of gas chromatography
(27), mass spectrometry (28), ${ }^{1} \mathrm{H}$ NMR spectrometry (29) and ${ }^{13} \mathrm{C}$ NMR spectrometry (30). As a potent tool, ${ }^{13} \mathrm{C}$ NMR spectroscopy was effectively applied to the conformational and configurational analyses. Based on the spectral examination, assignments of glycosidic and configurational linkages in each glycoside were accomplished. As shown in Table 2, the ${ }^{13} \mathrm{C}$ NMR spectral examination on $\mathrm{C}-2$ in the alkyl $\alpha$-L-sorbosides indicated that the synthesized alkyl L-sorbosides had an $\alpha$-Lsorbopyranoside form. On gas chromatographical analyses, it was confirmed that the purity of each alkyl $\alpha$-L-sorbopyranoside was 98 99\%.

Among n-pentyl glycosides, $n$-pentyl $\alpha$ L-sorbopyranoside given s.c. and p.o. suppressed the IgE antibody formation significantly in mice immunized with DNP-As (Table 1). However, the HA formation, estimated with pooled sera, was not suppressed. In p.o. administration, n-pentyl glycosides were dissolved in $2 \% \mathrm{NaHCO}_{3}$ solution to prevent $n$-pentyl glycosides from degradation by gastric juice (3). In the present results, it was confirmed that $n$ pentyl $\alpha$-L-sorbopyranoside was effective when administered p.o. In these experiments, $n$-pentyl $\beta$-L-fructopyranoside was less suppressive than $n$-pentyl $\alpha$-L-sorbopyranoside. Besides, $n$-pentyl $\alpha$-L-sorbopyranoside had the highest yield. Therefore, the structure-activity relationships of alkyl $\alpha$-L-sorbopyranosides were examined. In 
synthesized alkyl $\alpha$-L-sorbopyranosides, nbutyl and $\mathrm{n}$-pentyl $\alpha$-L-sorbopyranosides were found to suppress the $\lg E$ antibody formation in both rats and mice, while no suppressive effect of these compounds on the HA formation was observed (Tables 3 and 4). These results suggest that the $n$-butyl or $n$ pentyl residue in the $\alpha$-L-sorbopyranoside ring is necessary for eliciting the suppressing effect.

In all the experiments discussed above, alkyl glycosides were given to the animals after the immunization. Since timing of administration is an important factor which has an effect on the immunization, it was examined using $\mathrm{n}$-butyl and $\mathrm{n}$-pentyl $\alpha$-Lsorbopyranosides and $n$-pentyl $\beta$-Dfructopyranoside. As shown in Table 6, when these compounds were administered before the 2nd immunization, the secondary $\operatorname{lgE}$ antibody response of each group was suppressed significantly, although the HA formation was significantly enhanced. Though the mechanism of the significant enhancement of HA formation observed only in this experiment is not clear, it is sure that these compounds are not suppressive for the HA formation. Next, the dose-dependencies of these compounds were examined. As shown in Table 7, n-pentyl $\alpha$-L-sorbopyranoside suppressed the $\lg E$ antibody formation in doses of $20 \sim 200 \mathrm{mg} / \mathrm{kg}$, but a clear dose-dependent action was not observed. n-Butyl $\alpha$-L-sorbopyranoside and $n$-pentyl $\beta$-D-fructopyranoside, however, were less suppressive than $n$-pentyl $\alpha$-Lsorbopyranoside in this experiment.

The toxicity of $\mathrm{n}$-pentyl $\alpha$-L-sorbopyranoside is very low (Table 5), and the effect is expected to be antigen-independent, because this compound has no relation with any antigenic substance. Accordingly, the possibility of $n$-pentyl $\alpha$-L-sorbopyranoside as a new type of antiallergic agent is fully expected. Both $\mathrm{n}$-pentyl $\alpha$-L-sorbopyranoside and $n$-pentyl $\beta$-D-fructopyranoside having a ketohexopyranose conformation showed a similar suppression of the $\operatorname{lgE}$ antibody formation. The $n$-pentyl residue in a glycoside form of ketohexopyranose might participate in the suppression of the $\lg E$ antibody formation.
Further experiments on mechanisms of the action of $\mathrm{n}$-pentyl $\alpha$-L-sorbopyranoside are in progress.

\section{References}

1 Koda, A., Yanagihara, Y., Nagai, $H$. and Sakamoto, K.: Effect of certain Chinese drugs on reaginic antibody-induced allergic reaction. Folia Pharmacol. Japon. 69, 88P (1973) (in Japanese)

2 Yagi, A., Koda, A., Inagaki, N., Haraguchi, Y., Noda, K., Okamura, N. and Nishioka, I.: Studies on the constituents of Zizyphi Fructus. IV. Isolation of an anti-allergic component, ethy! $\alpha$-D-fructofuranoside from ethanol extract of Zizyphi Fructus. Yakugaku Zasshi 101, 700-707 (1981) (in Japanese)

3 Haraguchi, Y., Yagi, A., Koda, A., Inagaki, N., Noda, K. and Nishioka, I.: A specific inhibitor of $\lg E$ antibody formation: $n$-pentyl $\beta$-Dfructopyranoside. J. Med. Chem. 25, 14951499 (1982)

4 Strejan, G. and Campbell, D.H.: Hypersensitivity to Ascaris antigen. IV. Production of homocytotropic antibodies in the rat. J. Immunol. 101, 628-637 (1968)

5 Eisen, H.N., Belman, S. and Carsten, M.E.: The reaction of 2,4-dinitrobenzene sulfonic acid with free amino group of proteins. J. Am. Chem. Soc. 75, 4583-4585 (1953)

6 Itzhaki, R.F. and Gill, D.M.: A micro-biuret method for estimating proteins. Anal. Biochem. 9, 401-410 (1964)

7 Levine, B.B. and Vaz, N.M.: Effect of combinations of inbred strain, antigen, and antigen dose on immune responsiveness and reagin production in the mouse. Int. Arch. Allergy 39, 156-171 (1970)

8 Tada, T. and Okumura, K.: Regulation of homocytotropic antibody formation in the rat. I. Feedback regulation by passively administered antibody. J. Immunol. 106, 1002-1011 (1971)

9 Ovary, Z.: Passive cutaneous anaphylaxis in the mouse. J. Immunol. 81, 355-357 (1958)

10 Avrameas, S., Taudou, B. and Chuilon, S.: Glutaraldehyde, cyanuric chloride and tetraazotized o-dianisidine as coupling reagents in passive hemagglutination test. Immunochemistry 6, 67-76 (1969)

11 Ogawa, R.: Medical Statistics for Clinicians. p. 97-99. Shinko-Koueki, Tokyo (1981)(in Japanese)

12 Ishizaka, K., Ishizaka, T. and Hornbrook, M.M.: Physico-chemical properties of human reaginic antibody. IV. Presence of a unique immuno- 
globulin as a carrier of reaginic activity. $J$. Immunol. 97, 75-85 (1966)

13 Ishizaka, K., Okudaira, H. and King, T.P.: Immunogenic properties of modified antigen $\mathrm{E}$. II. Ability of urea-denatured antigen and $\alpha$ polypeptide chain to prime $T$ cells specific for antigen E. J. Immunol. 114, 110-115 (1975)

14 Takatsu, K. and Ishizaka, K.: Reaginic antibody formation in the mouse. VI. Suppression of IgE and $\operatorname{lgG}$ antibody responses to ovalbumin following the administration of high dose of urea-denatured antigen. Cell. Immunol. 20, 276-289 (1975)

15 Takatsu, K. and Ishizaka, K.: Reaginic antibody formation in the mouse. VIII. Depression of the ongoing IgE antibody response by suppressor $T$ cells. J. Immunol. 117, 1211-1218 (1976)

16 Lee, W.Y. and Sehon, A.H.: Abrogation of reaginic antibodies with modified allergens. Nature 267, 618-619 (1977)

17 Usui, M. and Matsuhashi, T.: IgE-selective and antigen-specific unresponsiveness in mice. I. Induction of the unresponsiveness by administration of ovalbumin-pullulan conjugate. J. Immunol. 122, 1266-1272 (1979)

18 Lee, W.Y. and Sehon, A.H.: Suppression of reaginic antibody formation. I. Induction of hapten-specific tolerance. J. Immunol. 114, 829-836 (1875)

19 Kishimoto, T., Hirai, Y., Suemura, M. and Yamamura, Y.: Regulation of antibody response in different immunoglobulin classes. I. Selective suppression of anti-DNP IgE antibody response by preadministration of DNP-coupled mycobacterium. J. Immunol. 117, 396-404 (1976)

20 Watanabe, N., Kojima, S. and Ovary, Z. Tolerizing effect of DNP-Ficoll on $\mathrm{lgE}$ antibody production. J. Immunol. 118, 251-255 (1977)

21 Schwenk, R., Lee, W.Y. and Sehon, A.H.:
Specific suppression of anti-hapten reaginic antibody titers with hapten-coated liposomes. J. Immunol. 120, 1612-1615 (1978)

22 Hubbard, D.A., Lee, W.Y. and Sehon, A.H.: Suppression of the anti-DNP IgE response with tolerogenic conjugates of DNP with polyvinyl alcohol. J. Immunol. 126, 407-413 (1981)

23 Strannegard, O. and Belin, L.: Suppression of reagin synthesis in rabbits by passively administered antibody. Immunology 18, 775-785 (1970)

24 Ngan, J. and Kind, L.S.: Suppressor T cells for $\lg E$ and $\lg G$ in Peyer's patches of mice made tolerant by the oral administration of ovalbumin. J. Immunol. 120, 861-865 (1978)

25 Fox, P.C. and Siraganian, R.P.: IgE antibody suppression following aerosol exposure to antigen. Immunology 43, 227-234 (1981)

26 Nakashima, S., Kanada, T. and Takatsu, K.: Suppressive effect of the extract of Baikisei and Saiko on the $\operatorname{lgE}$ antibody response in mice. Proc. Symp. Wakan-yaku 13, 42-46 (1980)

27 Gee, M. and Walker, H.G., Jr.: Gas-liquid chromatography of some methylated mono-, diand trisaccharides. Anal. Chem. 34, 650-653 (1962)

28 Heynes, K. and Huller, D.: Massenspektrometrische Untersuchungen. VI. Massenspektrometrische Untersuchung Deuteriummarkierter Methyl-2,3,4-tri-o-methyl- $\beta$-arabopyranoside. Tetrahedron 21, 55-68 (1965)

29 Angyal, S.J. and Pickles, V.A.: Equilibria between pyranoses and furanoses. Aust. J. Chem. 25, 1695-1710 (1972)

30 Que, L., Jr. and Gray, G.R.: C-Nuclear magnetic resonance spectra and tautomeric equilibria of ketohexoses in solution. Biochemistry 13, 146153 (1974) 